\title{
Meta-analysis Reveals Different Competition Effects on Tree Growth Resistance and Resilience to Drought
}

\author{
Daniele Castagneri, ${ }^{1,2}{ }^{*} \odot$ Giorgio Vacchiano, ${ }^{3} \odot$ Andrew Hacket-Pain, ${ }^{4} \odot$ \\ R. Justin DeRose, ${ }^{5} \odot$ Tamir Klein, ${ }^{6} \odot$ and Alessandra Bottero ${ }^{2,7} \odot$
}

${ }^{1}$ Department TESAF, Università degli Studi di Padova, 35020 Legnaro, Italy; ${ }^{2}$ Swiss Federal Institute for Forest, Snow and Landscape Research (WSL), 8903 Birmensdorf, Switzerland; ${ }^{3}$ Department DISAA, Università degli Studi di Milano, 20133 Milan, Italy; ${ }^{4}$ Department of Geography and Planning, School of Environmental Sciences, University of Liverpool, Liverpool L697ZT, UK; ${ }^{5}$ Department of Wildland Resources and Ecology Center, Utah State University, Logan, Utah 84322, USA; ${ }^{6}$ Department of Plant and Environmental Sciences, Weizmann Institute of Science (WIS), 7610001 Rehovot, Israel; ${ }^{7}$ SwissForestLab, 8903 Birmensdorf, Switzerland

\begin{abstract}
Drought will increasingly threaten forest ecosystems worldwide. Understanding how competition influences tree growth response to drought is essential for forest management aiming at climate change adaptation. However, published results from individual case studies are heterogeneous and sometimes contradictory. We reviewed 166 cases from the peer-reviewed literature to assess the influence of stand-level competition on tree growth response to drought. We monitored five indicators of tree growth response: mean sensitivity (interannual tree ring width variability); association between inter-annual growth variability and water availability; resistance; recovery; and resilience to drought. Vote counting did not indicate a consistent effect of competition on mean sensitivity.
\end{abstract}

Received 2 December 2020; accepted 21 March 2021; published online 6 May 2021

Supplementary Information: The online version contains supplementary material available at https://doi.org/10.1007/s10021-021-0063 8-4.

Author Contributions DC and GV conceived the study. AB contributed to the research design. $\mathrm{DC}, \mathrm{GV}, \mathrm{AH}-\mathrm{P}, \mathrm{RJD}, \mathrm{TK}$ and $\mathrm{AB}$ carried out the literature search and extracted the data. DC and AB performed statistical analyses. DC drafted the paper, with input from GV, AH-P, RJD, TK and AB.

*Corresponding author; e-mail: daniele.castagneri@unipd.it
Conversely, higher competition for resources strengthened the association between water availability and inter-annual growth rates. Meta-analysis showed that higher competition reduced resistance $(p<0.001)$ and improved recovery $(p<0.05)$, but did not consistently affect resilience. Species, site and stand characteristics, and drought intensity were insignificant or poor predictors for the large variability among the investigated cases. Our review and meta-analysis show that competition does not affect the response of tree growth to drought in a unidirectional and universal way. Although density reduction (thinning) can alleviate growth declines during drought, the effects on growth after stress are uncertain. The large variability among investigated cases suggests that local-scale processes play a crucial role in determining such responses and should be explicitly evaluated and integrated into specific strategies for adaptation of forests to climate change.

Key words: climate change adaptation; drought response; forest management; meta-analysis; resilience components; review; stand density; tree radial growth; tree rings. 


\section{HighLIGHTS}

- It is often suggested that competition exacerbates drought influence on tree growth.

- We reviewed and ran meta-analysis on five descriptors of growth response to drought.

- Stand-level competition reduces tree growth resistance, but not growth resilience.

\section{INTRODUCTION}

Anthropogenic climate change is responsible for more frequent and intense droughts worldwide (IPCC 2013; Trenberth and others 2014). Chronic soil water deficits and extreme drought events are projected to increasingly affect most forest ecosystems at different spatio-temporal scales (Reyer and others 2015), influencing tree reproduction (Bogdziewicz and others 2020), regeneration (Clark and others 2016), primary productivity (Rita and others 2019), radial growth (Anderegg and others 2015), plant defenses (Anderegg and others 2016), and mortality (Allen and others 2015).

Tree responses to drought are species- and sitespecific (Vitasse and others 2019; DeSoto and others 2020), but also depend on forest structure (tree size, number, and distribution in the stand), which regulate resource supply, uptake, and use efficiency (Pretzsch and others 2013; Tsamir and others 2019). Stand density and individual tree size, typically measured as stem diameter at breast height (in lieu of the desirable but more difficult measurement of leaf area, Forrester 2019), determine stand-level competition (Weigelt and Jolliffe 2003) and directly affect water availability and uptake (Krajicek and others 1961; Moreno-Gutiérrez and others 2012). A dense tree cover is associated with high rainfall interception by the canopy, subsequent evaporation of water before it reaches the soil, and reduced soil water storage (Molina and del Campo 2012). A dense canopy (high leaf area index) causes higher stand-level transpiration, which reduces soil water availability (Brèda and others 1995), yet it reduces daily maximum soil temperature and evaporation rates, particularly during dry-soil conditions (von Arx and others 2013). Notably, canopy influence on water evapotranspiration varies between tree species with different water-use behavior (anisohydric species have higher water-use than isohydric ones, Klein and others 2013) and crown architecture (for example, the decoupling of the canopy from the atmosphere is stronger for broadleaves than for conifers, Mag- nani and others 1998). Stand density also affects belowground competition for water, whose intensity increases linearly with the number of trees in the stand (Casper and Jackson 1997). Finally, competition exacerbates the effects of drought on tree functional processes, such as stomatal conductance and photosynthetic rate (Brèda and others 1995; Moreno and Cubera 2008; Tsamir and others 2019)-even though intrinsic water-use efficiency (that is, the ratio between photosynthetic assimilation and stomatal conductance) was found unaffected (Moreno-Gutiérrez and others 2012; Fernández-de-Uña and others, 2016).

By influencing soil water availability and tree physiological responses to water stress, competition eventually affects tree radial growth. Some largescale studies have shown a negative influence of stand density on growth during and after drought (Sohn and others 2016; Bottero and others 2017), and most literature on adaptive forest management recommends thinning as a tool to reduce drought constraints on tree growth (Brang and others 2014; Keenan 2015; del Río and others, 2017; Ammer 2016; Vilà-Cabrera and others 2018; Field and others 2020). Nevertheless, other studies show that the effect of competition on growth responses may vary widely in size and direction (Gazol and Camarero 2016; Serra-Maluquer and others 2018; Mausolf and others 2018; van Mantgem and others 2020). The large heterogeneity of results in the literature calls for a new synthesis of research. Identifying general patterns and specific drivers of the effect of competition on tree growth response to drought is critical to better understanding mechanisms of forest response to global warming. Furthermore, reviewing existing knowledge is key for planning effective management actions to maintain forest ecosystem services under climate change (Bolte and others 2009; Clark and others 2016).

In this paper, we investigated five widely used tree ring-based descriptors of growth response to drought: mean sensitivity, a measure of inter-annual tree ring width variability; association between inter-annual growth variability and water stress; growth resistance (Lloret and others 2011), which quantifies the growth reduction during a specific drought event; recovery, to assess the capacity to recover relative to the drought-induced growth reduction; and resilience, which measures the capacity of growth to return to the pre-disturbance performance. The three indices proposed by Lloret and others (2011) do not capture all aspects of tree response to drought, and recent papers have proposed integrations to evaluate tree responses to 
environmental stress in a more comprehensive way (see Gessler and others 2020; Nikinmaa and others 2020; Schwarz and others 2020). Still, these indices have been and still are widely used (Vitasse and others 2019; Gillerot and others 2020; DeSoto and others 2020). We analyzed results and data reported in the literature with the aim of assessing the influence of stand-level competition on tree growth response to drought. Specifically, we expected that (1) competition differently affects the five response descriptors (mean sensitivity, association of growth variability with water stress, resistance, recovery and resilience); (2) moderators such as climate, species, and stand characteristics influence the relationship between competition and resistance, recovery and resilience; (3) literature biases, study design, and local factors within individual studies affect our understanding of competition-drought interactions in forest stands.

\section{Materials AND Method}

\section{Literature Search and Database Building}

The literature search was performed using the Scopus database and the search engine Google Scholar, considering papers published until September 2020 included. The search keyword combination used was: "forest* OR tree*" AND "growth OR tree ring" AND "competition OR density" AND "drought*". An initial check of the title and abstract of several hundred papers allowed us to exclude irrelevant studies, that is, not related to competition and drought influence on tree radial growth. After screening of the full papers, we retained 69 studies (papers) that included analyses on the influence of stand-level competition on at least one of the five descriptors of growth response to drought. Each study included one or more cases (166 in total). A case corresponded to one species in one site. Each site included at least two stands with different basal area. Responses to different drought events were considered separately, but consecutive dry years were included in the same case. For each case, we recorded: bibliometric data, including the publication year; site location, including geographical coordinates; climate information, that is, annual mean temperature and precipitation sum; the reported drought year (or years); tree species; stand characteristics, such as species composition (mixed or pure), age, and basal area; the shade and drought tolerance of the species studied, measured on a 1-5 scale (from Niinemets and Valladares 2006); year of the last thinning (if any) before the drought; sample size (number of sampled trees); study design, that is, "observational," when stands of different basal area were investigated without density manipulation, or "treatment," which involved comparisons among different thinning intensities (Supplementary Table 1). We characterized each of the investigated drought events (as identified by the reference study) using the Standardized Precipitation-Evapotranspiration Index (SPEI, Vicente-Serrano and others 2010), calculated for integration periods of 3, 6, 9, 12, and 15 months, from month 1 (January for the northern hemisphere; previous year July for the southern hemisphere) to month 12 (December for the northern hemisphere; June for the southern hemisphere). SPEI was calculated using Thornthwaite's potential evapotranspiration computed from monthly air temperature and precipitation data at $0.5^{\circ}$ resolution (period of coverage 19012017) from the CRU TS dataset v. 4.02 (Harris and others 2014).

\section{Five Descriptors of Growth Response to Drought}

To assess growth response to drought, we used five descriptors widely used in the literature: the mean sensitivity, the association between inter-annual growth variability and water availability/water stress indices, and the three resilience components, that is, resistance, recovery, and resilience to drought events (Lloret and others 2011). The mean sensitivity measures the inter-annual variability of tree ring width series. It does not directly assess the relationship between growth and climatic variability, nor the response to extreme events. Despite criticism (Bunn and others 2013), this index is still widely used to assess how much tree growth depends on external factors, including water availability (Weber and others 2013; Hoffmann and others 2018). The association between growth variability and precipitation or drought indices can be measured by correlation, uni- and multivariate regression, or mixed models (Fritts 1976; Guiot 1991). Strong associations with climate variability can be due to either growth reductions during stressful years, or growth increases in favorable years. Therefore, this method cannot discriminate the specific response to drought. The three components of resilience (Lloret and others 2011) assess the growth responses during and in the years immediately following the drought. In contrast to the mean sensitivity and growth association with precipitation variability, they distinguish between positive and negative responses. Furthermore, as they are measured on a specific period (in contrast 
to mean sensitivity and response to climate, assessed over multi-decadal series), it is possible to reliably associate them with stand attributes (for example, stand density) measured in the same period.

When available, we retrieved mean sensitivity, growth-climate association, resistance, recovery and resilience values reported in the papers. When not available, resistance, recovery and resilience were calculated from data extracted from published graphics using WebPlotDigitizer v. 4.1 (Rohatgi 2011 ). Stand basal area was used as an indicator of stand-level competition intensity. Stand basal area depends on tree number and size (both influencing stand-level competition), is reported consistently in many papers, and has been often used to assess stand-level competition (Young and others 2017; Etzold and others 2019). In particular, to quantitatively assess competition for stands included in a case study, we calculated the relative basal area, that is, the ratio between the stand basal area and the maximum basal area for the species among the stands investigated in the study. The influence of competition on the five descriptors of growth response to drought was investigated using two different approaches: vote counting and metaanalysis.

\section{Vote Counting}

We used vote counting to assess the number of cases when competition had a negative or positive effect on the five descriptors of growth response to drought. We assigned the label "negative" to the cases where competition exacerbated the negative effects of drought, that is, when trees in stands with higher basal area exhibited: higher mean sensitivity, stronger association with inter-annual variability of drought or precipitation, lower resistance, recovery or resilience to drought events. The label "positive" was assigned to the opposite cases and "neutral" to cases where no differences were detected. When available, quantitative data on the resilience components were used to assess negative, positive, or neutral competition effects. However, qualitative information found in the papers could not be used for quantitative assessment. Therefore, vote counting on qualitative data allowed us to investigate more cases than the quantitative metaanalysis described below. Due to the low power of vote counting (Hunter and Schmidt 2004; Borenstein and others 2009; Cooper and others 2009), we did not use it to quantify the influence of competition on drought response descriptors, but to assess whether the number of positive and negative cases was similar or not, using a sign (binomial) test.

\section{Statistical Meta-analysis}

Meta-analysis was performed to test for competition effects on resistance (79 cases with quantitative information, excluding outliers), recovery (56 cases), and resilience (58 cases). A much lower number of cases (27) reported competition effects on mean sensitivity, which we did not consider sufficiently robust for a statistical meta-analysis. The association between growth and precipitation/drought was not measured consistently: early studies used correlation or response function analysis (Fritts 1976), whereas most recent studies used more complex methods such as linear mixed models. Therefore, we did not perform a statistical meta-analysis on this descriptor either.

As an "effect size" for meta-analysis, we used the slope of the linear relationship between stand relative basal area and each resilience component, computed for each case. Negative (positive) slopes indicate that stands with higher relative basal area have lower (higher) resistance, or recovery or resilience (Figure 1). Relative basal area and resilience components were calculated using the same scale for all cases, and thus, the regression slope served as a comparable metric, indicating both the size and direction of the investigated effect (Hunter and Schmidt 2004). The meta-analysis was computed using the package Metafor (Viechtbauer 2010) for the R statistical framework (R Core Team 2019). We fitted a random-effects model to estimate the mean effect size of competition on resilience components, under the assumptions that the cases included in our analysis were a random sample of a greater population of cases and that the true effect size varied from case to case, and the mean effect was an estimator of the mean of the distribution of effect sizes (Borenstein and others 2009; Viechtbauer 2010). We computed separate models for resistance, recovery, and resilience. Outliers (cases with a slope \pm 3 standard deviations from the mean slope across all cases) were removed (Viechtbauer and Cheung 2010), and the dependent variable (slope) was sin-transformed to reduce kurtosis and improve normality. In all models, weight argument was used to give more weight to studies with larger samples (more trees). A restricted maximum-likelihood estimator was used to assess the degree of heterogeneity in the effect sizes (Metafor's default). Model outcomes included the grand mean effect size, its $95 \%$ confidence intervals, and heterogeneity measures. 


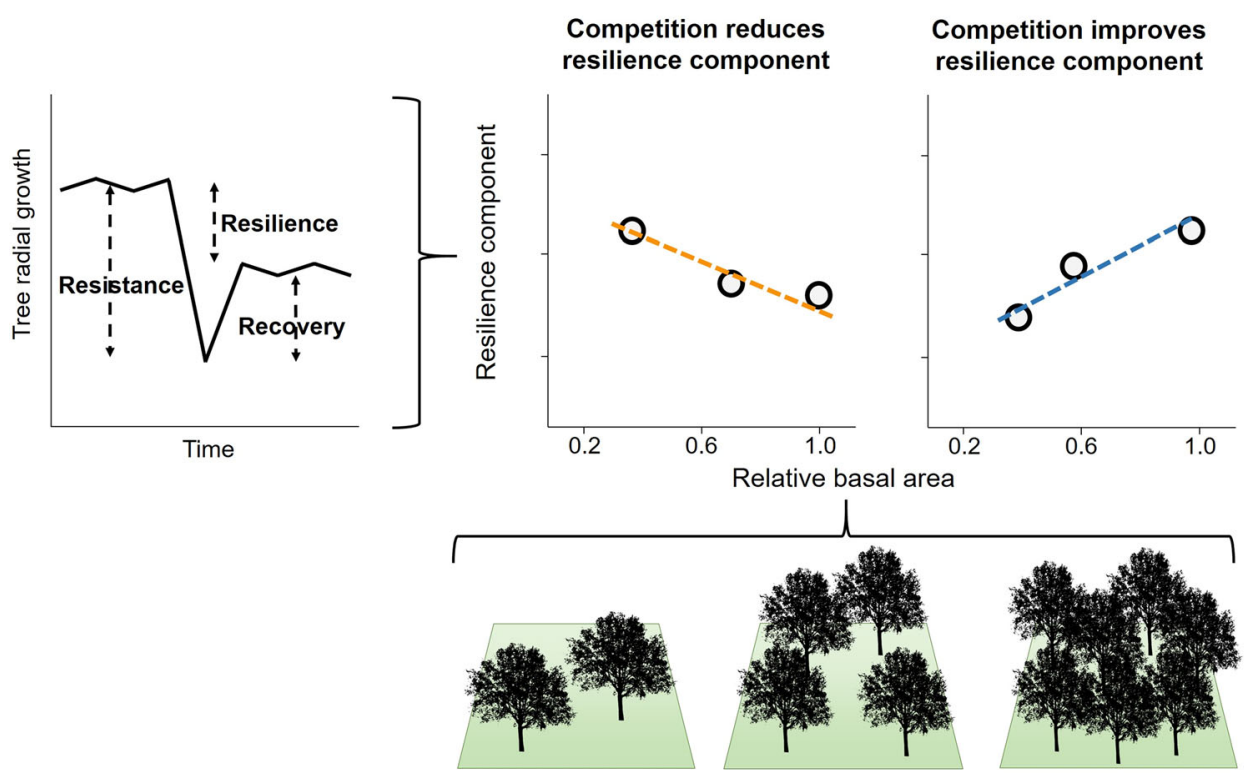

Figure 1. Schematic representation of the assessment of effect size in the meta-analysis. For each case, we computed the slope of the linear relationship between relative stand basal area (relative to the maximum basal area reported for the species by each study, $x$ axis) and resilience component (growth resistance, recovery, and resilience separately, $y$ axis). Negative (positive) slopes indicate that stands with higher relative basal area have lower (higher) resistance, recovery or resilience, that is, that competition reduces (improves) the resilience component.

Finally, we assessed the influence of different moderators on the effect size by meta-regression (Borenstein and others 2009). As fixed factors, we used tree species, functional type (conifer/broadleaf), species-specific shade and drought tolerance, stand composition (pure/mixed), mean tree age, age structure (even/uneven-aged), year of the last thinning (if any) before the drought, the study design (observational with no treatment/stand density manipulation treatment), site mean annual temperature and precipitation sum. Site was assigned as a random factor. Since all SPEI timescales were strongly cross-correlated, we retained only the one providing the most consistent results for each resilience component in the final meta-regression model. Backwards selection of predictors was performed based on the corrected Akaike information criterion.

\section{Sensitivity Analysis and Publication Bias}

Sensitivity analysis was used to test robustness of the meta-analysis results, that is, if they were sensitive to effect size metrics and data structure (Koricheva and Gurevitch 2014). First, we ran the models using stand relative basal area calculated on the maximum absolute basal area for the species (species-specific), calculated as a function of mean wood specific gravity according to Woodall and others (2005). Furthermore, we used the leavelout function in the Metafor package for $\mathrm{R}$, which assesses the influence of each case on the model outcome by recalculating the models leaving out one observation at a time (Viechtbauer 2010). Finally, we ran the models without removing the outliers (Viechtbauer and Cheung 2010; Thabane and others 2013). To assess the potential bias of sample size (Hunter and Schmidt 2004) and time of publications (Koricheva and Gurevitch 2014) on meta-analytical models, we scrutinized scatterplots and calculated Kendall's correlation coefficient between effect size and (1) study sample size or (2) publication year.

\section{Results}

\section{Vote Counting and Relationships Between the Three Resilience Components}

Our dataset comprised studies mostly from temperate regions of North America and Europe. Conifers were more represented than broadleaves, pure more than mixed stands, and even-aged more than uneven-aged stands (Figure 2, Supplementary Table 1). A similar number of cases showed positive $(41 \%)$ and negative $(37 \%)$ effects of standlevel competition on tree-ring mean sensitivity (binomial sign test, probability $=0.48, p=0.99$ ) (Figure 3$)$. The association between growth and 

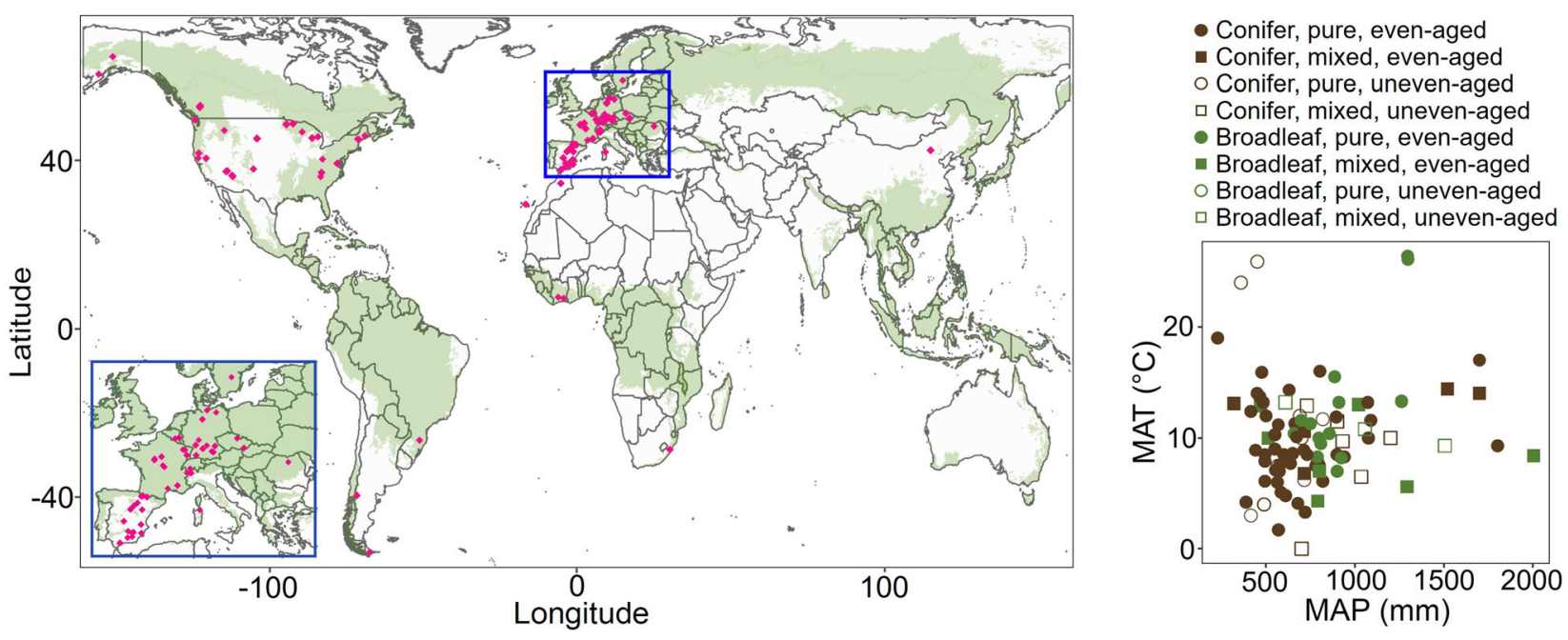

Figure 2. Locations of reviewed studies (left, magenta diamonds on the world forested land, in green) and scatterplot (right) of the corresponding mean annual temperature (MAT) and precipitation (MAP). See the key for correspondence between symbols and stand characteristics in the scatterplot.

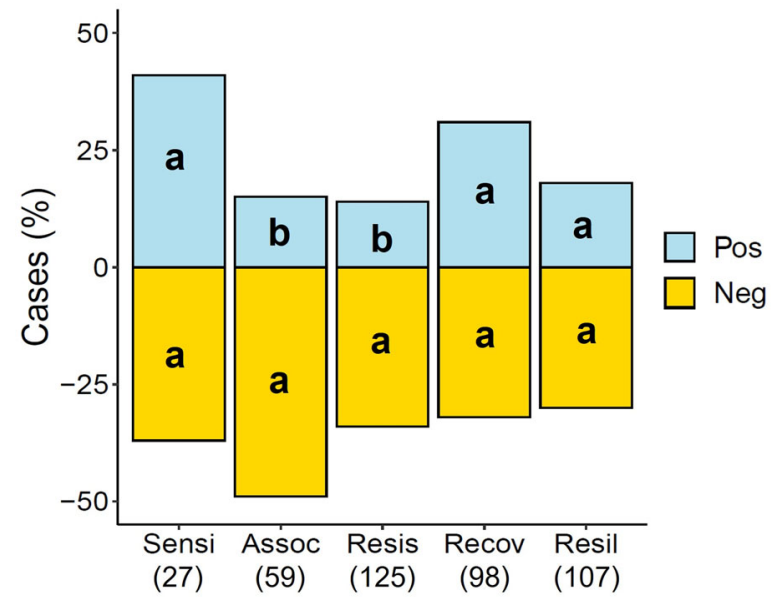

Figure 3. Relative frequency of cases with positive and negative effects of competition (stand basal area) on mean sensitivity (Sensi), climate-growth association (Assoc), resistance (Resis), recovery (Recov), and resilience (Resil). Neutral cases are not shown (positive, negative and neutral sum to $100 \%$ ). The total number of cases is reported below each descriptor. Different letters in the bars indicate significant differences in counts of negative and positive cases within each descriptor according to the binomial sign test $(p<0.05)$.

inter-annual precipitation (or drought) variability was stronger in higher- versus lower-density stands in $49 \%$ of cases, while only $15 \%$ of cases showed the opposite pattern (probability $=0.76, p<0.01$ ). More than half of cases ( $52 \%$ ) showed no significant competition effect on resistance to drought. However, when significant effects occurred, higher density stands had lower resistance in most cases (probability $=0.72, p<0.01)$. No significant difference occurred between positive and negative counts of cases that reported competition effects on recovery (probability $=0.51, p=0.99$ ) and resilience (probability $=0.63, p=0.09$ ). For cases with quantitative information, mean resistance was 0.70 , mean recovery was 1.66 , and mean resilience was 0.96 . The three resilience components were significantly related to each other. In particular, recovery was strongly negatively related to resistance (Spearman's $\rho=-0.66, \quad p<0.001$ ), whereas resilience was less strongly but positively related to recovery $(\rho=0.39, p<0.001)$ and resistance $(\rho=0.36, p<0.001)$.

\section{Meta-analysis on Growth Resistance}

Resistance to drought was generally lower in denser stands. The overall mean effect size, that is, the average slope of the linear relationship between site-specific stand relative basal area and resistance to drought, was $-0.133(p<0.001$; Table 1, Figure 4). However, high variability occurred among the investigated cases, as indicated both by high variance of the true effect sizes $\left(\tau^{2}=0.089\right)$, and high inconsistency across the different cases $\left(I^{2}=94.3\right)$. Moderators that describe site, stand, or species characteristics were not able to further explain this variability (Table 1; Figure 5; Supplementary Table 2). However, the sampling design affected the size effect estimate $(p<0.01)$, with cases from treatment studies showing lower size effects compared to cases from observational studies. The 3-month SPEI at the end of summer 
Table 1. Statistics for the Random-Effect and Meta-regression Models

\begin{tabular}{|c|c|c|c|c|c|c|c|c|c|}
\hline & $d \mathbf{f}$ & $\tau^{2}$ & $\tau$ & $I^{2}(\%)$ & $H^{2}$ & Estim & s.e & $p$ & AICc \\
\hline \multicolumn{10}{|c|}{ Random-eff. model } \\
\hline Resistance & 78 & 0.089 & 0.299 & 94.3 & 17.6 & -0.133 & 0.036 & $<0.001$ & 44.5 \\
\hline Recovery & 55 & 0.209 & 0.458 & 97.5 & 40.2 & 0.132 & 0.063 & 0.037 & 78.3 \\
\hline Resilience & 57 & 0.111 & 0.333 & 94.8 & 19.2 & -0.039 & 0.047 & 0.400 & 48.6 \\
\hline \multicolumn{10}{|c|}{ Meta-regr. model } \\
\hline Resistance & 76 & 0.076 & 0.276 & 93.1 & 14.5 & & & & 37.4 \\
\hline Intercept & & & & & & 0.096 & 0.102 & 0.349 & \\
\hline SPEI & & & & & & -0.074 & 0.037 & 0.045 & \\
\hline Observ/treat & & & & & & -0.289 & 0.107 & 0.007 & \\
\hline \multicolumn{10}{|c|}{ Meta-regr. model } \\
\hline Recovery & 45 & 0.180 & 0.425 & 97.1 & 34.6 & & & & 62.6 \\
\hline Intercept & & & & & & 0.204 & 0.140 & 0.146 & \\
\hline SPEI & & & & & & 0.141 & 0.069 & 0.041 & \\
\hline Thin. year & & & & & & 0.012 & 0.009 & 0.199 & \\
\hline \multicolumn{10}{|c|}{ Meta-regr. model } \\
\hline Resilience & 56 & 0.096 & 0.309 & 93.9 & 16.5 & & & & 42.6 \\
\hline Intercept & & & & & & -0.136 & 0.054 & 0.012 & \\
\hline SPEI & & & & & & -0.124 & 0.042 & 0.003 & \\
\hline \multicolumn{10}{|c|}{$\begin{array}{l}\text { df are the degrees of freedom, } \tau^{2} \text { is the estimate of total amount of heterogeneity in the size effect, that is, the slope of the linear relationship between each resilience component } \\
\text { (resistance, recovery, and resilience) and the stand relative basal area calculated on the maximum value for the species in the study (site-specific); } \tau \text { is the square root of the } \\
\text { estimate of total heterogeneity; } I^{2}(\%) \text { is the percentage of total variability due to heterogeneity; } H^{2} \text { is the ratio between total variability and within-study variance; estim. is the } \\
\text { estimate of the mean size effect for random-effect models, and of moderators for meta-regression models; se. is the estimate standard error; } p \text { indicates the estimate significance, } \\
\text { AICc is the corrected Akaike's information criterion of the model; intrcpt is the intercept; SPEI is the Standardized Precipitation-Evapotranspiration Index calculated for } \\
\text { different periods (for resistance, from July to September for the northern hemisphere, from January to March for the southern hemisphere; for recovery, from January to } \\
\text { September for the northern hemisphere, from previous year July to current year March for the southern hemisphere; for resilience, from previous year August to current year } \\
\text { April for the northern hemisphere, from previous year February to previous year October for the southern hemisphere); Thin. year is the number of years from the last thinning } \\
\text { (if any) before drought; Observ/treat is the study design, that is, "observational," for comparisons between non-manipulated stands with different basal areas, or "treatment," } \\
\text { which involved comparisons between different thinning intensities. }\end{array}$} \\
\hline
\end{tabular}

(March for the southern hemisphere, September for the northern hemisphere) significantly improved the meta-regression model fit $(p<0.05)$, as the influence of competition on resistance was stronger for moderate, rather than for severe, droughts (Table 1; Supplementary Table 3). When using species-specific (instead of site-specific) relative basal area to assess competition influence on resistance, we obtained slightly more heterogeneous results (Supplementary Table 4), but the mean effect size and its significance were unchanged. Model outputs were robust to influential cases and outliers. Indeed, removal of one observation at a time did not affect mean effect size estimate (always negative at $p<0.001$; Supplementary Table 5). Inclusion of outliers increased heterogeneity, but had a negligible effect on the mean effect size (Supplementary Table 6).

\section{Meta-analysis on Growth Recovery}

The average slope (mean effect size) of the relationship between relative stand basal area and recovery was $+0.132(p=0.04$; Table 1 , Figure 4$)$, that is, recovery was generally higher in denser stands. The heterogeneity among the investigated cases was higher than for resistance $\left(\tau^{2}=0.209\right.$; $\left.I^{2}=97.5\right)$. The 9-month SPEI at the end of summer (March for the southern hemisphere, September for the northern hemisphere) and the number of years elapsed between the drought and the last thinning had a positive influence on the effect size (Table 1; Figure 5). As for resistance, using speciesspecific relative basal area resulted in slightly higher heterogeneity (Supplementary Table 4), but in this case, the mean effect size was not significant. Leaving out one observation at a time (Supplementary Table 5) slightly affected effect size estimates. Inclusion of outliers increased the heterogeneity statistics and the mean effect size (Supplementary Table 6).

\section{Meta-analysis on Growth Resilience}

The mean effect of competition on resilience was not significant $(-0.039, p=0.40)$ (Table 1, Figure 4). Heterogeneity was intermediate between that of resistance and recovery $\left(\tau^{2}=0.111\right.$; $I^{2}=94.8$ ). The 9-month SPEI at mid-spring (October for the southern hemisphere, April for the northern hemisphere) negatively affected the effect size $(p<0.01 ;$ Table 1$)$. The model on species- 

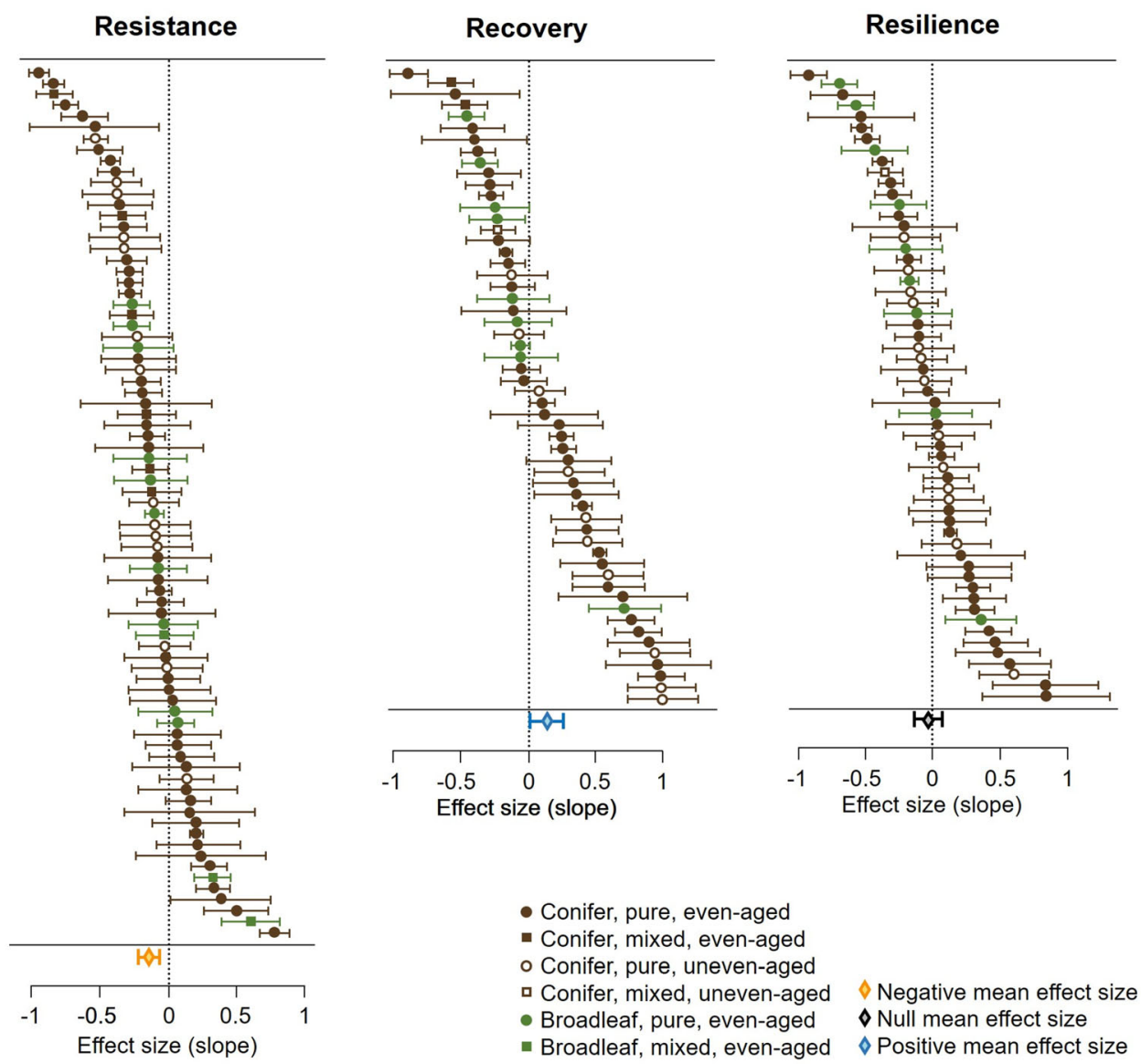

Figure 4. Graphical display (forest plots) of the estimated results of meta-analysis on resistance (left panel), recovery (central panel), and resilience (right panel). For each case, the circle or the square (see the key for symbol description) represents the effect size, that is, the slope of the linear relationship between site-specific relative basal area and resistance, recovery, and resilience, with confidence interval bars. Dotted vertical lines separate positive and negative slopes. Diamonds (see the key for symbol description) at the bottom of the plots display the mean effect size, with confidence interval bars, estimated in the random-effect meta-analysis model.

specific relative basal area provided similar size effect estimate (Supplementary Table 4). Removal of one observation at a time did not lead to significant effect size estimate, nor did the inclusion of outliers improve the model fit (Supplementary Tables 5 and 6).

\section{Publication Bias}

For resistance, recovery, and resilience, studies based on larger samples showed more negative effect sizes (for both models using species-specific or site-specific relative basal area, Supplementary Fig. 2 and Supplementary Table 7). Publication year did not affect the effect size in any model (Supplementary Fig. 3 and Supplementary Table 7).

\section{Discussion}

General Patterns of Competition Effects on Tree Growth Response to Drought

Our synthesis of research shows that the influence of competition on tree growth response to drought is highly variable. Although the literature often assumes that high stand density exacerbates drought influence on growth (Ammer 2016; del Río and others 2017; Pretzsch 2020; van Mantgem and others 2020), our analysis demonstrates that such an effect is not universal and differs across the investigated response descriptors. Mean sensitivity, an estimate of growth dependency on environmental variability, was not consistently affected by competition (vote counting analysis). However, in most investigated cases, a tighter coupling of growth to water availability was observed in high- 

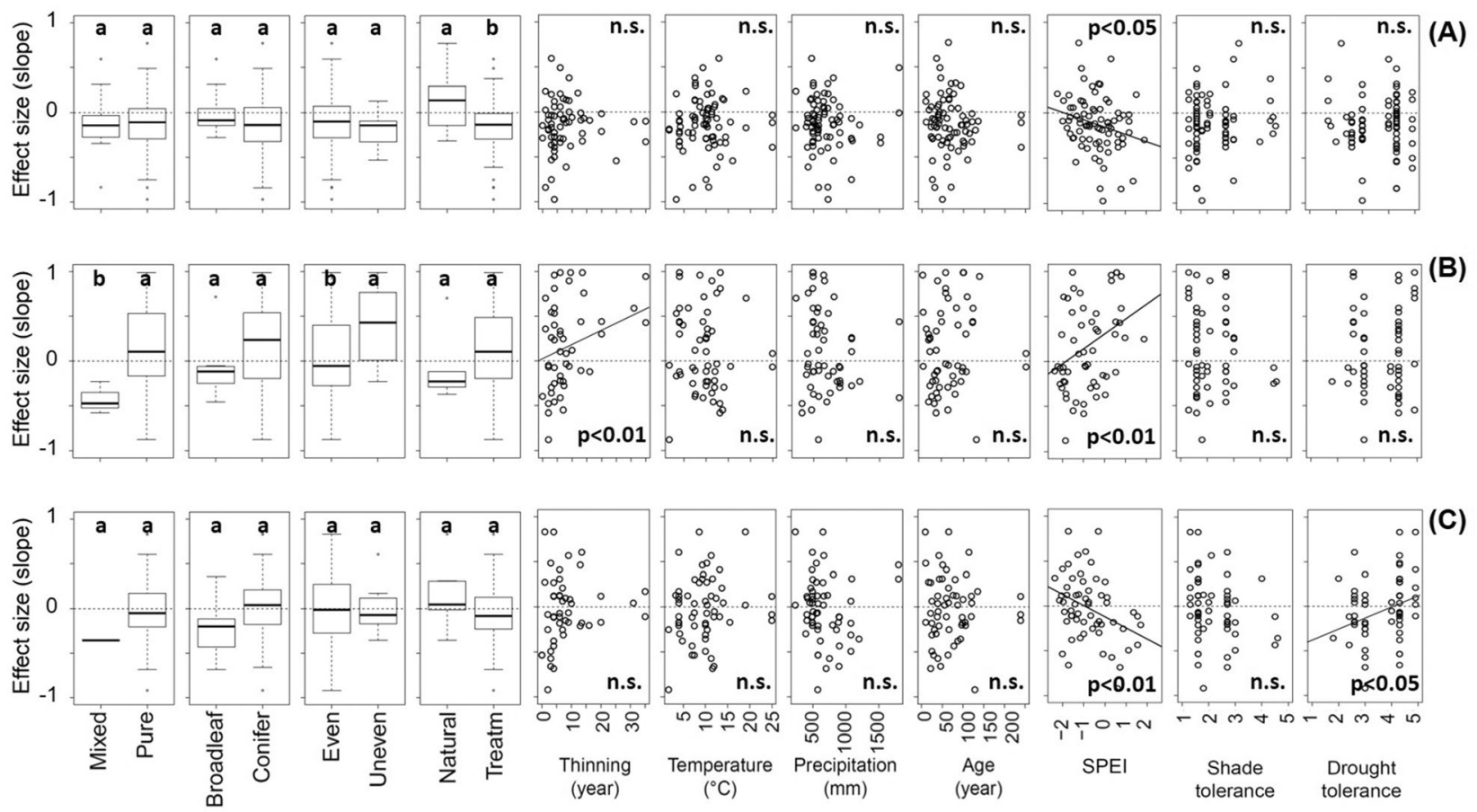

Figure 5. Resistance $(\mathbf{A})$, recovery $(\mathbf{B})$, and resilience $(\mathbf{C})$ effect size across stand and climate characteristics, drought intensity (SPEI) and species shade and drought tolerance. For resistance, SPEI is computed from July to September in the northern hemisphere, from January to March in the southern hemisphere. For recovery, SPEI is computed from January to September in the northern hemisphere, from previous year July to current year March in the southern hemisphere. For resilience, SPEI is computed from previous year August to current year April in the northern hemisphere, from previous year February to previous year October in the southern hemisphere. In the boxplots, different letters correspond to significantly different means. In the scatterplots, regression line (solid line) is presented for significant models $(p<0.05)$.

er- versus lower-density stands, contradicting the classical idea that competition reduces inter-annual growth variability, and masks climate influence on radial growth (Schweingruber and others 1990).

The three components of resilience were differentially affected by competition. Overall resistance, which quantifies the growth reaction during drought events, was lower in stands with higher basal area. Trees in dense stands have higher rainfall interception, lower access to groundwater and faster water depletion (López and others 2003; Annighöfer 2018). Therefore, during dry years, soil water deficit starts earlier and becomes more severe for trees in denser stands, resulting in stronger growth reduction (Brèda and others 1995; Brown and others 2005; Moreno and Cubera 2008; Klein and others 2013). Although lower competition intensity generally mitigated tree growth reduction during drought, it did not systematically improve resilience. One possible explanation is that competition does not directly affect tree functional and structural traits that allow trees to return to predisturbance growth rates (Moreno-Gutiérrez and others 2012; Fernández-de-Uña and others 2016).
Also, drought carry-over effects are not always more severe in denser stands due to higher water depletion (Brown and others 2005; Clark and others 2016).

Somewhat unexpectedly, competition had a positive influence on recovery; however, before inferring possible ecological and physiological causes, we must consider interdependence between the resilience components (Lloret and others 2011; Pretzsch and others 2013). As calculated in our dataset, recovery was strongly and negatively related to resistance, as also found by Gazol and others (2018), Hoffmann and others (2018), and Schwarz and others (2020). Because denser stands had, on average, lower resistance than low-density stands, but resilience was on average constant, recovery was also inevitably higher in high-density stands. Such inter-relationships (particularly between resistance and recovery) should be considered before interpreting the outcome of this, or any analysis of resilience components. 


\section{Large Variability Among Cases}

The lack of universal patterns of competitive influence on growth response to drought, in particular for recovery and resilience, was likely due to multiple causes. First, the assessment of the three resilience component indices was quite variable among studies (for example, different sampling design, reference period for the indices computation, criteria for drought identification), and this can lead to different results as extensively discussed by Schwarz and others (2020). The computation of resilience and recovery components is particularly problematic, as the time for recovery varies across species and site conditions (Anderegg and others 2015; Gessler and others 2020).

The observed variability could be also related to climate, site, and stand differences among cases, which we explored through meta-regression. Tree response to drought is certainly species-specific (McDowell and others 2008; Klein 2014; Anderegg and others 2015; DeSoto and others 2020), but we found that competition effects on the resilience components did not differ between conifers and broadleaves, and among species with different drought and shade tolerance. Yet, we cannot exclude differences among species at the local scale or for specific drought events, as they might depend on factors not investigated in our analysis, such as soil characteristics and site-specific phenology (Lévesque and others 2014; Merlin and others 2015; Gillerot and others 2020).

The intensity of drought can also play a critical role on tree response to water stress (Kannenberg and others 2019). For moderate droughts, we found larger differences in resistance, recovery, and resilience between low- and high-density stands, whereas during intense drought events, all stands were similarly affected irrespective of density. This corroborates the idea that the stand-level competition influence on resistance is mostly related to soil water availability. Denser stands deplete water storage earlier (Simonin and others 2007; Cabon and others 2018; Andrews and others 2020), and thus soil moisture deficit occurs even during moderate droughts. However, during strong and prolonged dry periods, soil water is depleted even in low-density stands, which then experience significant growth reduction. Still, the intensity of drought depends not only on meteorological conditions (as assessed through the SPEI), but also on topography and soil characteristics. This information is inconsistently reported across studies (for example, different soil classification systems, different measures of soil water potential, and con- tent), but future research ought to consider such factors at the stand scale (Field and others 2020).

The intensity and timing of thinning likely affects tree growth response to drought. Despite the general positive effects of density reduction on tree physiology (Giuggiola and others 2016), heavy thinning likely stresses the remaining trees for a few years. For example, canopy microclimate can be strongly altered, increasing individual tree transpiration in the immediate post-intervention period (Aussenac 2000; Tsamir and others 2019). This might explain why we observed both positive and negative effects of recent thinning on recovery. Furthermore, heavy crown cover reduction might increase soil evaporation and surface runoff for many years, especially at xeric sites, or promote colonization of shrubs that compete for water in the upper soil layers (Brown and others 2005; Raz-Yaseef and others 2010). In contrast, low reductions in density might be ineffective at increasing stand water availability during droughts (Stednick 1996). Intermediate densities could represent the best compromise between high stand leaf area, which rapidly exhausts water availability, and low crown cover, which exposes the soil to evaporation and understory transpiration (Gebhardt and others 2014; Cabon and others 2018). Such nonlinear influence of stand density on drought responses deserves more investigation in future studies. Furthermore, the effects of thinning are variable in time (D'Amato and others 2013; Sohn and others 2013). For example, any positive effect of light thinning might vanish after few years, due to canopy closure. A single thinning operation can improve stand conditions for just a few years, and regular management is needed to the maintenance of reduced stand densities in the long term (Pretzsch 2020).

\section{Research Gaps and Indications for Future Studies}

Our review revealed interesting geographical shortcomings within the available literature, knowledge gaps, and possible research biases. The majority of the studies we included came from pure conifer stands in temperate regions. Scant information was available for broadleaves, which respond differently to drought than conifers (Anderegg and others 2015; De Soto and others 2020), and for mixed forests, which might be more drought resistant than pure forests (Pretzsch and others 2013; Gillerot and others 2020). Unfortunately, there were few studies available from semiarid and tropical regions, the southern hemisphere, and Asia. This was partially due to the 
shortage of species forming annual rings in these regions (Zhao and others 2019), which make impossible the calculation of tree ring-based descriptors of growth response to drought. Somewhat surprisingly, northern countries with long forestry tradition such as Canada, Russia, and Fennoscandian countries were also underrepresented. Future investigation in these areas, also susceptible to increasing drought (Allen and others 2015), is urgently needed.

The number of papers considered in our analysis increased in recent years, but the outcomes of these studies did not change over time (no temporal bias, Koricheva and Gurevitch 2014). However, we noted that some titles, abstracts and conclusions stress the negative effect of competition on the three resilience components, despite significant results that occurred for only some species, sites or drought events. The tendency to publish studies, or to highlight results, in agreement with current theories is a common pattern in many research fields (Dickersin 2005). Specifically, we argue that there is likely a risk to convey that high competition always reduces growth resistance and/or resilience to drought, while our meta-analysis clearly demonstrates that is not the case.

We also explored how the study design influenced research outcomes, to provide indications for future research. The cases from "treatment" studies, as well as those based on a larger number of sampled trees, showed more consistent size effects (especially for resistance) compared to "observational" studies and those based on few trees. Applying different silvicultural treatments to homogenous stands ("treatment" studies) is important if one wants to discern the effect of competition from other factors that can influence growth response to drought. Confounding factors cannot be ruled out when comparing stands differing in competition intensity for natural causes (as for "observational" studies).

\section{Implications for Forest Management}

The results of our review and meta-analysis have important implications for management strategies aimed at mitigating the negative impacts of drought on forest growth. Although most literature recommends thinning to improve growth resilience to drought, we did not find support for an overall negative effect of competition on this component. The unexpected positive influence of competition on recovery was likely due to the inverse relationship of this component with resistance. This calls into question not only current recommenda- tions to improve tree growth after drought, but more generally, poses an issue with respect to how we assess forest capacity to return to the initial, or a new stable-state state, after disturbance (resilience and recovery), as discussed in recent papers (Gessler and others 2020; Nikinmaa and others 2020; Schwarz and others 2020; Albrich and others 2020). However, we showed that reducing competition in high-density stands can increase growth resistance to drought. Still, large and mostly unexplained variability among the investigated cases emphasizes the need for more extensive research, especially in underrepresented regions and for mixed and broadleaf stands, and an integration of mechanistic information to better understand tree-water relationships. We suggest that future studies seeking to determine the competition effects on growth response to drought should explicitly consider the particularities of the species, stand, stage of development and local climate. Identifying the factors acting on the interactions between competition and drought at the local scale can improve management strategies aimed at building forest adaptive capacity.

\section{ACKNOWLEDGEMENTS}

Daniele Castagneri was supported by a Marie Skłodowska-Curie Fellowship (H2020-MSCA-IF2017 - 788951). Alessandra Bottero acknowledges support from the Federal Office for the Environment FOEN (Grant No. 05.0602.PZ/P382-0487). This research was supported by the Utah Agricultural Experiment Station, Utah State University, and approved as journal Paper Number 9314.

\section{FUNDING}

Open access funding provided by Università degli Studi di Padova within the CRUI-CARE Agreement.. Open access funding provided by Università degli Studi di Padova within the CRUI-CARE Agreement.

\section{OPEN ACCESS}

This article is licensed under a Creative Commons Attribution 4.0 International License, which permits use, sharing, adaptation, distribution and reproduction in any medium or format, as long as you give appropriate credit to the original author(s) and the source, provide a link to the Creative Commons licence, and indicate if changes were made. The images or other third party material in this article are included in the article's Creative Commons licence, unless indicated otherwise in a 
credit line to the material. If material is not included in the article's Creative Commons licence and your intended use is not permitted by statutory regulation or exceeds the permitted use, you will need to obtain permission directly from the copyright holder. To view a copy of this licence, visit $h$ ttp://creativecommons.org/licenses/by/4.0/.

\section{DATA AVAILABILITY}

The dataset used in this study is available as Supplementary material.

\section{REFERENCES}

Albrich K, Rammer W, Turner MG, Ratajczak Z, Braziunas KH, Hansen WD, Seidl R. 2020. Simulating forest resilience: a review. Glob Ecol Biogeogr 29:2082-2096.

Allen CD, Breshears DD, McDowell NG. 2015. On underestimation of global vulnerability to tree mortality and forest dieoff from hotter drought in the Anthropocene. Ecosphere 6:155.

Ammer C. 2016. Unraveling the importance of inter- and intraspecific competition for the adaptation of forests to climate change. In: Cánovas F, Lüttge U, Matyssek R, Eds. Progress in botany. Cham: Springer. pp 345-67.

Anderegg WRL, Klein T, Bartlett M, Sack L, Pellegrini AFA, Choat B, Jansen S. 2016. Meta-analysis reveals that hydraulic traits explain cross-species patterns of drought-induced tree mortality across the globe. Proc Natl Acad Sci 1 13:5024-5029.

Anderegg WRL, Schwalm C, Biondi F, Camarero JJ, Koch G, Litvak M, Ogle K, Shaw JD, Shevliakova E, Williams AP, Wolf A, Ziaco E, Pacala S. 2015. Pervasive drought legacies in forest ecosystems and their implications for carbon cycle models. Science 349:528-532.

Andrews CM, D'Amato AW, Fraver S, Palik B, Battaglia MA, Bradford JB. 2020. Low stand density moderates growth declines during hot droughts in semi-arid forests. J Appl Ecol 57:1089-1102.

Annighöfer P. 2018. Stress relief through gap creation? Growth response of a shade tolerant species (Fagus sylvatica L.) to a changed light environment. For Ecol Manag 415-416:139147.

Aussenac G. 2000. Interactions between forest stands and microclimate: ecophysiological aspects and consequences for silviculture. Ann For Sci 57:287-301.

Bogdziewicz M, Kelly D, Thomas PA, Lageard JGA, Hacket-Pain A. 2020. Climate warming disrupts mast seeding and its fitness benefits in European beech. Nat Plants 6:88-94.

Bolte A, Ammer C, Löf M, Madsen P, Nabuurs G-J, Schall P, Spathelf P, Rock J. 2009. Adaptive forest management in central Europe: climate change impacts, strategies and integrative concept. Scand J For Res 24:473-482.

Borenstein M, Hedges L, Rothstein H. 2009. Introduction to meta-analysis. Wiley.

Bottero A, D'Amato AW, Palik BJ, Bradford JB, Fraver S, Battaglia MA, Asherin LA. 2017. Density-dependent vulnerability of forest ecosystems to drought. J Appl Ecol 54:1605-1614.

Brang P, Spathelf P, Larsen JB, Bauhus J, Bončína A, Chauvin C, Drössler L, García-Güemes C, Heiri C, Kerr G, Lexer MJ,
Mason B, Mohren F, Mühlethaler U, Nocentini S, Svoboda M. 2014. Suitability of close-to-nature silviculture for adapting temperate European forests to climate change. Forestry 87:492-503.

Brèda N, Granier A, Aussenac G. 1995. Effects of thinning on soil and tree water relations, transpiration and growth in an oak forest (Quercus petraea (Matt.) Liebl.). Tree Physiol 15:295306.

Brown AE, Zhang L, McMahon TA, Western AW, Vertessy RA. 2005. A review of paired catchment studies for determining changes in water yield resulting from alterations in vegetation. J Hydrol 310:28-61.

Bunn AG, Jansma E, Korpela M, Westfall RD, Baldwin J. 2013. Using simulations and data to evaluate mean sensitivity $(\zeta)$ as a useful statistic in dendrochronology. Dendrochronologia 31:250-254.

Cabon A, Mouillot F, Lempereur M, Ourcival JM, Simioni G, Limousin JM. 2018. Thinning increases tree growth by delaying drought-induced growth cessation in a Mediterranean evergreen oak coppice. For Ecol Manag 409:333-342.

Casper BB, Jackson RB. 1997. Plant competition underground. Annu Rev Ecol Syst 28:545-570.

Clark JS, Iverson L, Woodall CW, Allen CD, Bell DM, Bragg DC, D'Amato AW, Davis FW, Hersh MH, Ibanez I, Jackson ST, Matthews S, Pederson N, Peters M, Schwartz MW, Waring KM, Zimmermann NE. 2016. The impacts of increasing drought on forest dynamics, structure, and biodiversity in the United States. Glob Change Biol 22:2329-2352.

Cooper H, Hedges LV, Valentine JC. 2009. The handbook of research synthesis and meta-analysis, 2nd edn. Russell Sage Foundation.

D'Amato AW, Bradford JB, Fraver S, Palik BJ. 2013. Effects of thinning on drought vulnerability and climate response in north temperate forest ecosystems. Ecol Appl 23:1735-1742.

del Río M, Bravo-Oviedo A, Pretzsch H, Löf M, Ruiz-Peinado R. 2017. A review of thinning effects on scots pine stands: from growth and yield to new challenges under global change. For Syst 26:eR03S.

DeSoto L, Cailleret M, Sterck F, Jansen S, Kramer K, Robert EMR, Aakala T, Amoroso MM, Bigler C, Camarero JJ, Čufar K, Gea-Izquierdo G, Gillner S, Haavik LJ, Hereş AM, Kane JM, Kharuk VI, Kitzberger T, Klein T, Levanič T, Linares JC, Mäkinen H, Oberhuber W, Papadopoulos A, Rohner B, Sangüesa-Barreda G, Stojanovic DB, Suárez ML, Villalba $R$, Martínez-Vilalta J. 2020. Low growth resilience to drought is related to future mortality risk in trees. Nat Commun 11:1-9.

Dickersin K. 2005. Publication bias: recognizing the problem, understanding its origins and scope, and preventing harm. In: Publication bias in meta-analysis: prevention, assessment and adjustments. Wiley. pp 9-33.

Etzold S, Ziemińska K, Rohner B, Bottero A, Bose AK, Ruehr NK, Zingg A, Rigling A. 2019. One century of forest monitoring data in Switzerland reveals species- and site-specific trends of climate-induced tree mortality. Front Plant Sci 10:307.

Fernández-de-Uña L, Mcdowell NG, Cañellas I, Gea-Izquierdo G. 2016. Disentangling the effect of competition, $\mathrm{CO}_{2}$ and climate on intrinsic water-use efficiency and tree growth. J Ecol 104:678-690.

Field JP, Breshears DD, Bradford JB, Law DJ, Feng X, Allen CD. 2020. Forest management under megadrought: urgent needs at finer scale and higher intensity. Front For Glob Change 3:502669. 
Forrester DI. 2019. Linking forest growth with stand structure: tree size inequality, tree growth or resource partitioning and the asymmetry of competition. For Ecol Manag 447:139-157.

Fritts HC. 1976. Tree rings and climate. London: Academic Press.

Gazol A, Camarero JJ, Vicente-Serrano SM, Sánchez-Salguero R, Gutiérrez E, de Luis M, Sangüesa-Barreda G, Novak K, Rozas V, Tíscar PA, Linares JC, Martín-Hernández N, Martínez del Castillo E, Ribas M, García-González I, Silla F, Camisón A, Génova M, Olano JM, Longares LA, Hevia A, Tomás-Burguera M, Galván JD. 2018. Forest resilience to drought varies across biomes. Glob Change Biol 24:2143-2158.

Gazol A, Camarero JJ. 2016. Functional diversity enhances silver fir growth resilience to an extreme drought. J Ecol 104:10631075.

Gebhardt T, Häberle KH, Matyssek R, Schulz C, Ammer C. 2014. The more, the better? Water relations of Norway spruce stands after progressive thinning. Agric For Meteorol 197:235-243.

Gessler A, Bottero A, Marshall J, Arend M. 2020. The way back: recovery of trees from drought and its implication for acclimation. New Phytol 228:1704-1709.

Gillerot L, Forrester DI, Bottero A, Rigling A, Lévesque M. 2020. Tree neighbourhood diversity has negligible effects on drought resilience of European beech, silver fir and Norway spruce. Ecosystems 24:1-17.

Giuggiola A, Ogée J, Rigling A, Gessler A, Bugmann H, Treydte K. 2016. Improvement of water and light availability after thinning at a xeric site: which matters more? A dual isotope approach. New Phytol 210:108-121.

Guiot J. 1991. The bootstrapped response function. Tree Ring Bull 51:39-41.

Harris I, Jones PD, Osborn TJ, Lister DH. 2014. Updated highresolution grids of monthly climatic observations-the CRU TS3.10 dataset. Int J Climatol 34:623-642.

Hoffmann N, Schall P, Ammer C, Leder B, Vor T. 2018. Drought sensitivity and stem growth variation of nine alien and native tree species on a productive forest site in Germany. Agric For Meteorol 256-257:431-444.

Hunter JE, Schmidt FL. 2004. Methods of meta-analysis: correcting error and bias in research findings. Newbury Park, CA: Sage Publications.

IPCC. 2013. Climate change 2013 the physical science basis: Working Group I contribution to the fifth assessment report of the intergovernmental panel on climate change.

Kannenberg SA, Maxwell JT, Pederson N, D'Orangeville L, Ficklin DL, Phillips RP. 2019. Drought legacies are dependent on water table depth, wood anatomy and drought timing across the eastern US. Ecol Lett 22:119-127.

Keenan RJ. 2015. Climate change impacts and adaptation in forest management: a review. Ann For Sci 72:145-167.

Klein T, Shpringer I, Fikler B, Elbaz G, Cohen S, Yakir D. 2013. Relationships between stomatal regulation, water-use, and water-use efficiency of two coexisting key Mediterranean tree species. For Ecol Manag 302:34-42.

Klein T. 2014. The variability of stomatal sensitivity to leaf water potential across tree species indicates a continuum between isohydric and anisohydric behaviours. Funct Ecol 28:13131320.

Koricheva J, Gurevitch J. 2014. Uses and misuses of metaanalysis in plant ecology. J Ecol 102:828-844.

Krajicek JE, Brinkman KA, Gingrich SF. 1961. Competition measure of density. For Sci 7:35-42.
Lévesque M, Rigling A, Bugmann H, Weber P, Brang P. 2014. Growth response of five co-occurring conifers to drought across a wide climatic gradient in Central Europe. Agric For Meteorol 197:1-12.

Lloret F, Keeling EG, Sala A. 2011. Components of tree resilience: effects of successive low-growth episodes in old ponderosa pine forests. Oikos 120:1909-1920.

López BC, Sabaté S, Gracia CA. 2003. Thinning effects on carbon allocation to fine roots in a Quercus ilex forest. Tree Physiol 23:1217-1224.

Magnani F, Leonardi S, Tognetti R, Grace J, Borghetti M. 1998. Modelling the surface conductance of a broad-leaf canopy: effects of partial decoupling from the atmosphere. Plant Cell Environ 21:867-879.

Mausolf K, Wilm P, Härdtle W, Jansen K, Schuldt B, Sturm K, von Oheimb G, Hertel D, Leuschner C, Fichtner A. 2018. Higher drought sensitivity of radial growth of European beech in managed than in unmanaged forests. Sci Total Environ 642:1201-1208.

McDowell N, Pockman WT, Allen CD, Breshears DD, Cobb N, Kolb T, Plaut J, Sperry J, West A, Williams DG, Yepez EA. 2008. Mechanisms of plant survival and mortality during drought: why do some plants survive while others succumb to drought? New Phytol 178:719-739.

Merlin M, Perot T, Perret S, Korboulewsky N, Vallet P. 2015. Effects of stand composition and tree size on resistance and resilience to drought in sessile oak and Scots pine. For Ecol Manag 339:22-33.

Molina AJ, del Campo AD. 2012. The effects of experimental thinning on throughfall and stemflow: a contribution towards hydrology-oriented silviculture in Aleppo pine plantations. For Ecol Manag 269:206-213.

Moreno G, Cubera E. 2008. Impact of stand density on water status and leaf gas exchange in Quercus ilex. For Ecol Manag 254:74-84.

Moreno-Gutiérrez C, Battipaglia G, Cherubini P, Saurer M, NicolÁS E, Contreras S, Querejeta JI. 2012. Stand structure modulates the long-term vulnerability of Pinus halepensis to climatic drought in a semiarid Mediterranean ecosystem. Plant Cell Environ 35:1026-1039.

Niinemets $\ddot{U}$, Valladares F. 2006. Tolerance to shade, drought, and waterlogging of temperate northern hemisphere trees and shrubs. Ecol Monogr 76:521-547.

Nikinmaa L, Lindner M, Cantarello E, Jump AS, Seidl R, Winkel G, Muys B. 2020. Reviewing the use of resilience concepts in forest sciences. Curr For Rep 6:61-80.

Pretzsch H. 2020. Density and growth of forest stands revisited. Effect of the temporal scale of observation, site quality, and thinning. For Ecol Manag 460:117879.

Pretzsch H, Schütze G, Uhl E. 2013. Resistance of European tree species to drought stress in mixed versus pure forests: evidence of stress release by inter-specific facilitation. Plant Biol 15:483-495.

R Core Team. 2019. R: a language and environment for statistical computing. Vienna, Austria. https://www.r-project.org/

Raz-Yaseef N, Rotenberg E, Yakir D. 2010. Effects of spatial variations in soil evaporation caused by tree shading on water flux partitioning in a semi-arid pine forest. Agric For Meteorol 150:454-462.

Reyer CPO, Brouwers N, Rammig A, Brook BW, Epila J, Grant RF, Holmgren $M$, Langerwisch $F$, Leuzinger S, Lucht W, Medlyn B, Pfeifer M, Steinkamp J, Vanderwel MC, Verbeeck 
H, Villela DM. 2015. Forest resilience and tipping points at different spatio-temporal scales: approaches and challenges. J Ecol 103:5-15.

Rita A, Camarero JJ, Nolè A, Borghetti M, Brunetti M, Pergola N, Serio C, Vicente-Serrano SM, Tramutoli V, Ripullone F. 2019. The impact of drought spells on forests depends on site conditions: the case of 2017 summer heat wave in southern Europe. Glob Change Biol 26:851-863.

Rohatgi A. 2011. WebPlotDigitizer user manual. https://autome ris.io/WebPlotDigitizer/. Accessed 11 Aug 2020.

Schwarz J, Skiadaresis G, Kohler M, Kunz J, Schnabel F, Vitali V, Bauhus J. 2020. Quantifying Growth Responses Of Trees To Drought-A Critique Of Commonly Used Resilience Indices And Recommendations For Future Studies. Curr For Rep 6:185-200.

Schweingruber FH, Kairiukstis L, Shiyatov S. 1990. Sample selection. In: Cook ER, Kairiukstis LA, Eds. Methods of dendrochronology. Kluwer Academic Publishers. pp 23-35.

Serra-Maluquer X, Mencuccini M, Martínez-Vilalta J. 2018. Changes in tree resistance, recovery and resilience across three successive extreme droughts in the northeast Iberian Peninsula. Oecologia 187:343-354.

Simonin K, Kolb TE, Montes-Helu M, Koch GW. 2007. The influence of thinning on components of stand water balance in a ponderosa pine forest stand during and after extreme drought. Agric For Meteorol 143:266-276.

Sohn JA, Saha S, Bauhus J. 2016. Potential of forest thinning to mitigate drought stress: a meta-analysis. For Ecol Manag 380:261-273.

Sohn JA, Gebhardt T, Ammer C, Bauhus J, Häberle KH, Matyssek R, Grams TEE. 2013. Mitigation of drought by thinning: short-term and long-term effects on growth and physiological performance of Norway spruce (Picea abies). For Ecol Manag 308:188-197.

Stednick JD. 1996. Monitoring the effects of timber harvest on annual water yield. J Hydrol 176:79-95.

Thabane L, Mbuagbaw L, Zhang S, Samaan Z, Marcucci M, Ye C, Thabane M, Giangregorio L, Dennis B, Kosa D, Debono VB, Dillenburg R, Fruci V, Bawor M, Lee J, Wells G, Goldsmith CH. 2013. A tutorial on sensitivity analyses in clinical trials: the what, why, when and how. BMC Med Res Methodol 13:92.

Trenberth KE, Dai A, Van Der Schrier G, Jones PD, Barichivich J, Briffa KR, Sheffield J. 2014. Global warming and changes in drought. Nat Clim Change 4:17-22.

Tsamir M, Gottlieb S, Preisler Y, Rotenberg E, Tatarinov F, Yakir D, Tague C, Klein T. 2019. Stand density effects on carbon and water fluxes in a semi-arid forest, from leaf to stand-scale. For Ecol Manag 453:117573.

van Mantgem PJ, Kerhoulas LP, Sherriff RL, Wenderott ZJ. 2020. Tree-ring evidence of forest management moderating drought responses: implications for dry, coniferous forests in the southwestern United States. Front For Glob Change 3:1-7.

Vicente-Serrano SM, Beguería S, López-Moreno JI, VicenteSerrano SM, Beguería S, López-Moreno JI. 2010. A Multiscalar drought index sensitive to global warming: the standardized precipitation evapotranspiration index. J Clim 23:1696-1718.

Viechtbauer W, Cheung MW-L. 2010. Outlier and influence diagnostics for meta-analysis. Res Synth Methods 1:112-125.

Viechtbauer W. 2010. Conducting meta-analyses in R with the metafor package. J Stat Softw 36:1-48.

Vilà-Cabrera A, Coll L, Martínez-Vilalta J, Retana J. 2018. Forest management for adaptation to climate change in the Mediterranean basin: a synthesis of evidence. For Ecol Manag 407:16-22.

Vitasse Y, Bottero A, Cailleret M, Bigler C, Fonti P, Gessler A, Lévesque M, Rohner B, Weber P, Rigling A, Wohlgemuth T. 2019. Contrasting resistance and resilience to extreme drought and late spring frost in five major European tree species. Glob Change Biol 25:3781-3792.

von Arx G, Graf Pannatier E, Thimonier A, Rebetez M. 2013. Microclimate in forests with varying leaf area index and soil moisture: potential implications for seedling establishment in a changing climate. J Ecol 101:1201-1213.

Weber P, Bugmann H, Pluess AR, Walthert L, Rigling A. 2013. Drought response and changing mean sensitivity of European beech close to the dry distribution limit. Trees Struct Funct 27:171-181.

Weigelt A, Jolliffe P. 2003. Indices of plant competition. J Ecol 91:707-720.

Woodall CW, Miles PD, Vissage JS. 2005. Determining maximum stand density index in mixed species stands for strategicscale stocking assessments. For Ecol Manag 216:367-377.

Young DJN, Stevens JT, Earles JM, Moore J, Ellis A, Jirka AL, Latimer AM. 2017. Long-term climate and competition explain forest mortality patterns under extreme drought. Ecol Lett 20:78-86.

Zhao S, Pederson N, D'Orangeville L, HilleRisLambers J, Boose E, Penone C, Bauer B, Jiang Y, Manzanedo RD. 2019. The International Tree-Ring Data Bank (ITRDB) revisited: data availability and global ecological representativity. J Biogeogr 46:355-368. 